\title{
Effect of storage and heat on antimicrobial proteins in human milk
}

\author{
T. J. EVANS, H. C. RYLEY, L. M. NEALE, J. A. DODGE, AND V. M. LEWARNE \\ From the Departments of Child Health and Medical Microbiology, Welsh National School of Medicine, and \\ St David's Hospital, Cardiff
}

SUMMARY Human milk, after storage and pastuerisation at $73^{\circ} \mathrm{C}$ for 30 minutes at a milk bank, was found to have little surviving $\mathrm{IgA}$, IgG, lactoferrin, lysozyme, and $\mathrm{C} 3$ complement. Accurate pasteurisation at $62.5^{\circ} \mathrm{C}$ produced a loss of $23.7 \%$ of the lysozyme, $56.8 \%$ of the lactoferrin, $34 \%$ of the IgG, but no loss of IgA. Storage by deep freezing at $-20^{\circ} \mathrm{C}$ for 3 months produced no appreciable loss of lactoferrin, lysozyme, IgG, IgA, or C3.

Human milk is thought by many paediatricians to be the best food for low birthweight infants (Davies et al., 1972). In England and Wales five large-scale human milk banks operate primarily for this purpose (Rolles, 1973) and most maternity units make some effort to collect milk for their special care babies. We question whether the final product after storage and processing has the same value for the preterm infant as feeding at the breast has for the mature one. Little is known of the best method of collection, storage, and processing of human milk and this paper is intended to draw attention to two aspects: the effect of heating and storing of human milk on its content of immunoglobulins and other antimicrobial factors.

\section{Methods}

Milk samples. Human milk was collected by mothers in their own homes, using glass Woolwich shells to obtain overflow milk. The milk was stored unfrozen in the family refrigerator for up to $\mathbf{4 8}$ hours, until collected by the staff of the Human Milk Bank, St David's Hospital, Cardiff. Aliquots of milk as it arrived at the milk bank were analysed either raw, after deep freezing for 3 months at $-20^{\circ} \mathrm{C}$, after lyophilisation and reconstitution, or after pasteurisation at the laboratory or milk bank.

Pasteurisation. This was achieved by placing bottles of milk into a steam-heated water bath. The holding temperature during the study was found to be $72^{\circ}$ to $73^{\circ} \mathrm{C}$ for 30 minutes, although the temperature aimed for was $65^{\circ} \mathrm{C}$. Cooling was achieved by circulating water at room temperature. Laboratory pasteurisa-

Received 19 July 1977 tion was performed by heating small $(2 \mathrm{ml})$ samples in an accurately regulated water bath and using constant agitation until the holding temperature was achieved, and then held for 30 minutes. Five temperatures $\left({ }^{\circ} \mathrm{C}\right)$ were used, $60^{\circ}, 62 \cdot 5^{\circ}, 65^{\circ}, 67 \cdot 5^{\circ}$, and $70^{\circ}$.

\section{Quantitative electroimmunoassay.}

Antigen and monospecific antiserum. Lysozyme was prepared by the method of Jollés and Jollés (1967) and lactoferrin prepared from human milk as previously described (Ryley, 1972). Monospecific antiserum to $\alpha_{1}$-antitrypsin, IgG, lactoferrin, and lysozyme was raised in rabbits (Ryley, 1972; Ryley and Brogan, 1973; Ryley et al., 1975). Antisera to C3 component of complement and IgA were obtained from Hoechst Pharmaceuticals, Hounslow, England.

Electroimmunoassay. $2 \mu \mathrm{l}$ volumes of either raw or treated milk were analysed by an electroimmunoassay method against monospecific antiserum in $1 \%$ agarose, or in the case of IgG $1 \%$ ion agar as previously described (Ryley and Brogan, 1973). Dilution of a laboratory control serum standardised against both a Behring human serum and plasma controls were used for the estimations of $\alpha_{1}$-antitrypsin, C3, IgA, and IgG. Dilutions of $1 \mathrm{mg} / \mathrm{ml}$ solution of both lysozyme and lactoferrin antigens were used in their appropriate assay. All estimations were carried out on duplicate plates.

\section{Results}

Raw milk. Table 1 shows the results of assays on 25 random donations to the milk bank. 
Table 1 Concentration of 6 proteins in human milk donated to a milk bank ( $\mathrm{mg} / 100 \mathrm{ml} \mathrm{milk})^{*}$

\begin{tabular}{llll}
\hline & No. of samples & Mean $\pm S E$ & Range \\
\hline$\alpha_{1}$-antitrypsin & 25 & $3.42 \pm 0.07$ & $1 \cdot 0-21 \cdot 2$ \\
C3 & 24 & $1 \cdot 77 \pm 0.018$ & $0 \cdot 7-4 \cdot 0$ \\
IgG & 25 & $0.43 \pm 0.04$ & $0 \cdot 2-2 \cdot 4$ \\
IgA & 25 & $7.96 \pm 0.12$ & $0.9-20.6$ \\
Lactoferrin & 25 & $419 \pm 77$ & $74-1606$ \\
Lysozyme & 25 & $5.9 \pm 1.4$ & $0.5-32.5$ \\
\hline
\end{tabular}

*Values in Tables 1-4 are given in traditional units, i.e. $\mathrm{mg} / 100 \mathrm{ml}$; to convert to $\mathrm{g} / \mathrm{l}$, multiply by 0.01 .

Table 2 Effect of milk bank pasteurisation on 6 milk proteins ( $\mathrm{mg} / 100 \mathrm{ml}$ milk)

\begin{tabular}{lcc}
\hline $\begin{array}{l}\text { Protein } \\
\text { (no. of samples) }\end{array}$ & $\begin{array}{l}\text { Raw milk } \\
\text { (mean } \pm S E)\end{array}$ & $\begin{array}{l}\text { Pasteurised milk } \\
\text { (mean } \pm S E)^{*}\end{array}$ \\
\hline$\alpha_{1}$-antitrypsin (16) & $2 \cdot 38 \pm 0 \cdot 30$ & $1 \cdot 47 \pm 0 \cdot 25(61 \cdot 8)$ \\
C3 (16) & $1 \cdot 35 \pm 0 \cdot 13$ & $<0 \cdot 1$ \\
IgA (16) & $5 \cdot 5 \pm 1 \cdot 10$ & $<0 \cdot 1$ \\
IgG (16) & $0 \cdot 42 \pm 0 \cdot 05$ & $<0 \cdot 1$ \\
Lysozyme (16) & $7 \cdot 3 \pm 2 \cdot 0$ & $0 \cdot 17 \pm 0 \cdot 1(2 \cdot 3)$ \\
Lactoferrin (16) & $337 \pm 57 \cdot 3$ & $3 \pm 1 \cdot 1(0 \cdot 9)$ \\
\hline
\end{tabular}

*Numbers in parentheses are means as \% of raw value.

Pasteurisation. There was marked destruction of activity after milk bank pasteurisation $\left(72^{\circ}-73^{\circ} \mathrm{C}\right)$ (Table 2). Only $\alpha_{1}$-antitrypsin showed any significant survival.

Table 3 shows the results of well-controlled heating under laboratory conditions for milk lysozyme, lactoferrin, IgG, and IgA at 5 temperatures, $60^{\circ}$, $62 \cdot 5^{\circ}, 65^{\circ}, 67 \cdot 5^{\circ}$, and $70^{\circ} \mathrm{C}$, each for 30 minutes. $\operatorname{IgA}$ survived with relatively little loss until the temperature of $70^{\circ} \mathrm{C}$ was used (33.3\% loss). IgG was much more labile, with $65^{\circ} \mathrm{C}$ producing a loss of $77 \cdot 2 \%$. Lactoferrin showed a similar pattern of thermolability with a slightly greater loss $(85 \%)$ at $65^{\circ} \mathrm{C}$.

The results for lysozyme showed a wide variation dependent on $\mathrm{pH}$. The mean results are shown in Table 3, but there were 5 samples of $\mathrm{pH} 6$ and 4 samples of pH 7. At $65^{\circ} \mathrm{C}$ there was a mean loss of $98.7 \%$ at $\mathrm{pH} 7$, but only a $27 \%$ loss at $\mathrm{pH} 6$.
Freezing and lyophilisation. Table 4 shows the results of 3 months' storage at $-20^{\circ} \mathrm{C}$, and of freeze-drying and reconstitution. There was no significant change in lactoferrin, lysozyme, IgA, IgG, and C3, after 3 months' freezing, but a small loss of IgG occurred after lyophilisation.

\section{Discussion}

The milk donations were up to 48 hours old, often heavily contaminated with bacteria (a recent study showed that nearly $50 \%$ of samples had $10^{6}$ organisms $/ \mathrm{ml}$ ) (C. H. L. Howells and T. J. Evans, unpublished 1975) and from the 'mature' phase of lactation, yet our results for lactoferrin and lysozyme compare favourably with published results (Bullen et al., 1972; Peitersen et al., 1975). Immunoglobulin levels and C3 were, however, quite low compared with the data of others (Mata and Wyatt, 1971; Peitersen et al., 1975), the loss possibly occurring during the 48 hours' storage at the mother's home. Szöllösy et al. (1974) showed a marked loss of antibody in human milk during periods of bacterial growth. Also, our IgA values were measured by using a 7S IgA standard and we have not attempted a conversion to secretory IgA as did Peitersen et al. (1975), which partly explains the lower values.

We found no published data for $\alpha_{1}$-antitrypsin in human milk though Laskowski and Laskowski (1951) measured total antitryptic activity and found it only in colostrum. Bullen et al. (1972) postulated that milk antitrypsins could protect lactoferrin from gastrointestinal trypsin and this encouraged us to include it in our studies as it could also help to protect milk proteins from milk proteases (Heyndrickx, 1962) or bacterial enzymes (Moore et al., 1964) during periods of storage in vitro.

There is a surprising lack of information on heat stability. Complement was expected to be labile, also expected was the greater survival of $\operatorname{IgA}$ compared with IgG. Lysozyme is heat stable at acid pH (Jollés

Table 3 Effect of pasteurisation for 30 minutes at $60^{\circ}, 62 \cdot 5^{\circ}, 65^{\circ}, 67 \cdot 5^{\circ}$, and $70^{\circ} \mathrm{C}$ on $\operatorname{IgA}, \operatorname{Ig} \mathrm{G}$, lysozyme, and lactoferrin $(\mathrm{mg} / 100 \mathrm{ml})$

\begin{tabular}{|c|c|c|c|c|c|c|}
\hline & \multirow[b]{2}{*}{$\begin{array}{c}\text { Raw milk } \\
(\text { mean } \pm S E)\end{array}$} & \multicolumn{5}{|l|}{ Pasteurisation } \\
\hline & & $\begin{array}{c}60^{\circ} \\
(m e a n \pm S E)\end{array}$ & $\begin{array}{c}62 \cdot 5^{\circ} \\
(m e a n \pm S E)\end{array}$ & $\begin{array}{c}65^{\circ} \\
(m e a n \pm S E)\end{array}$ & $\begin{array}{c}67 \cdot 5^{\circ} \\
(m e a n \pm S E)\end{array}$ & $\begin{array}{c}70^{\circ} \\
(\text { mean } \pm S E)\end{array}$ \\
\hline $\begin{array}{l}\text { IgG } 9 \text { samples } \\
\text { IgA } 6 \text { samples } \\
\text { Lactoferrin } 9 \text { samples } \\
\text { Lysozyme } 9 \text { samples }\end{array}$ & $\begin{array}{l}1 \cdot 05 \pm 0 \cdot 22 \\
15 \cdot 6 \pm 2 \cdot 3 \\
565 \pm 185 \\
3 \cdot 5 \pm 0 \cdot 94\end{array}$ & $\begin{array}{c}0.87 \pm 0 \cdot 45 \\
(82 \cdot 8) \\
16 \cdot 3 \pm 4 \cdot 8 \\
(105) \\
476 \pm 171 \\
(84 \cdot 3) \\
4 \cdot 06 \pm 0 \cdot 94 \\
(115 \cdot 6)\end{array}$ & $\begin{array}{c}0 \cdot 69 \pm 0 \cdot 13 \\
(66) \\
15 \cdot 8 \pm 2 \cdot 4 \\
(101) \\
244 \pm 79 \cdot 7 \\
(43 \cdot 2) \\
2 \cdot 68 \pm 0 \cdot 74 \\
(76 \cdot 3)\end{array}$ & $\begin{array}{c}0 \cdot 24 \pm 0 \cdot 6 \\
(22 \cdot 8) \\
14 \cdot 3 \pm 1 \cdot 9 \\
(91 \cdot 9) \\
83 \cdot 2 \pm 29 \\
(14 \cdot 7) \\
1 \cdot 35 \pm 0 \cdot 45 \\
(38 \cdot 6)\end{array}$ & $\begin{array}{c}0 \cdot 1 \pm 0 \cdot 05 \\
(9 \cdot 6) \\
13 \cdot 95 \pm 1 \cdot 7 \\
(89) \\
45 \cdot 2 \pm 16 \\
(8) \\
0 \cdot 53 \pm 0 \cdot 82 \\
(15 \cdot 2)\end{array}$ & $\begin{array}{c}0.027 \pm 0 \cdot 022 \\
(2 \cdot 6) \\
10 \cdot 56 \pm 1 \cdot 0 \\
(67 \cdot 7) \\
32 \pm 12 \cdot 3 \\
(5 \cdot 7) \\
0\end{array}$ \\
\hline
\end{tabular}

-Figures in parentheses are the means as \% of raw milk value. 
Table 4 Effect of deep freezing $(3 \mathrm{~m})$ at $-20^{\circ} \mathrm{C}$ and lyophilisation of human milk proteins $(\mathrm{mg} / 100 \mathrm{ml} \mathrm{milk})$

\begin{tabular}{|c|c|c|c|c|c|c|c|}
\hline & \multirow{2}{*}{$\begin{array}{l}\text { Raw milk } \\
(\text { mean } \pm S E)\end{array}$} & \multicolumn{3}{|c|}{ Deep frozen milk } & \multicolumn{3}{|c|}{ Lyophilised milk } \\
\hline & & $M e a n \pm S E$ & Mean as $\%$ raw & $\boldsymbol{P}$ & $M e a n \pm S E$ & Mean as $\%$ raw & $\boldsymbol{P}$ \\
\hline $\begin{array}{l}\alpha_{1} \text {-antitrypsin } 16 \text { samples } \\
\text { IgA } 8 \text { samples } \\
\text { IgG } 16 \text { samples } \\
\text { Lactoferrin } 11 \text { samples } \\
\text { Lysozyme } 11 \text { samples } \\
\text { C3 } 16 \text { samples }\end{array}$ & $\begin{array}{l}2 \cdot 38 \pm 0 \cdot 3 \\
9 \cdot 55 \pm 0 \cdot 84 \\
0 \cdot 42 \pm 0 \cdot 05 \\
332 \pm 71 \cdot 7 \\
5 \cdot 1 \pm 1 \cdot 26 \\
1 \cdot 35 \pm 0 \cdot 13\end{array}$ & $\begin{array}{l}1 \cdot 98 \pm 0 \cdot 2 \\
9 \cdot 25 \pm 0 \cdot 83 \\
0 \cdot 42 \pm 0 \cdot 04 \\
338 \pm 57 \cdot 4 \\
4 \cdot 6 \pm 0 \cdot 67 \\
1 \cdot 26 \pm 0 \cdot 11\end{array}$ & $\begin{array}{c}83 \cdot 2 \\
96 \cdot 9 \\
100 \\
102 \\
90 \cdot 2 \\
93 \cdot 3\end{array}$ & $\begin{array}{l}<0.05 \\
>0.1 \\
>0.1 \\
>0.1 \\
>0.1 \\
>0.1\end{array}$ & $\begin{array}{l}2 \cdot 22 \pm 0 \cdot 3 \\
9 \cdot 33 \pm 0 \cdot 74 \\
0 \cdot 33 \pm 0 \cdot 04 \\
363 \pm 79 \\
4 \cdot 8 \pm 1 \cdot 19 \\
1 \cdot 27 \pm 0 \cdot 13\end{array}$ & $\begin{array}{r}93 \cdot 3 \\
97 \cdot 7 \\
78 \cdot 6 \\
109 \cdot 3 \\
94 \cdot 1 \\
94 \cdot 1\end{array}$ & $\begin{array}{l}>0.1 \\
>0.1 \\
<0.05 \\
>0.1 \\
>0.1 \\
>0.1\end{array}$ \\
\hline
\end{tabular}

and Jollés, 1961) but very labile at the natural $\mathrm{pH}$ of human milk $(7 \cdot 2-7 \cdot 4)$ (Chandan et al., 1964), though during storage the fall in $\mathrm{pH}$ may aid survival. The apparent increase of lysozyme on heating to $60^{\circ} \mathrm{C}$ was probably due to release from the often large cellular component of human milk. Storage by deep freezing seemed a very satisfactory procedure and the more expensive lyophilisation showed no advantage.

Although breast feeding is both natural and advantageous to the normal term infant, doubt has been cast on its ability to provide optimal growth for the very preterm infant (Davies, 1977; Fomon and Ziegler, 1977). Autoclaving human milk as practised in some hospitals would also limit its antimicrobial advantage, especially as it has been shown that a breast milk substitute can produce a similar gut flora of lactobacilli (Willis et al., 1973).

We suggest that human milk should be collected in as sterile a manner as possible and deep frozen shortly after collection. If of low bacterial count then its use unheated should be considered. Pasteurisation, if used, should be at the minimum temperature capable of adequate bacterial killing (about $62^{\circ} \mathrm{C}$ for 30 minutes) (Szöllösy et al., 1974). Unfortunately, there does not seem to be a commercial apparatus available in the United Kingdom capable of dealing with small volumes and achieving uniform and accurate heating.

\section{References}

Bullen, J. J., Rogers, H. J., and Leigh, L. (1972). Iron binding proteins in milk and resistance to Escherichia coli infection in infants. British Medical Journal, 1, 69-75.

Chandan, R. C., Shahani, K. M., and Holly, R. G. (1964). Lysozyme content of human milk. Nature, 204, 76-77.

Davies, D. P. (1977). Adequacy of expressed breast milk for early growth of preterm infants. Archives of Disease in Childhood, 52, 296-301.

Davies, P. A., Robinson, R. J., Scopes, J. W., Tizard, J. P. M., and Wigglesworth, J. S. (1972). (Editors.) Medical Care of Newborn Babies, p. 96. Heinemann, London and Philadelphia.
Fomon, S. J., and Ziegler, E. E. (1977). Protein intake of premature infants-interpretation of data. Journal of Pediatrics, 90, 504-506.

Heyndrickx, G. V. (1962). Investigations on the enzyme content of human milk. Annales Paediatrici, 198, 356-362.

Jollés, P., and Jollés, J. (1961). Lysozyme from human milk. Nature, 192, 1187-1188.

Jollés, J., and Jollés, P. (1967). Human tear and human milk lysozymes. Biochemistry, 6, 411-417.

Laskowski, M., Jr., and Laskowski, M. (1951). Crystaline trypsin inhibitor from colostrum. Journal of Biological Chemistry, 190, 563-573.

Mata, L. J., and Wyatt, R. G. (1971). Host resistance to infection. American Journal of Clinical Nutrition, 24, 976-986.

Moore, E. C., Reichard, P., and Thelander, L. (1964). Enzymatic synthesis of deoxyribonucleotides. V. Purification and properties of thioredoxin reductase from Escherichia coli B. Journal of Biological Chemistry, 239, 3445-3452.

Peitersen, B., Bohn, L., and Andersen, H. (1975). Quantitative determination of immunoglobulins, lysozyme, and certain electrolytes in breast milk. Acta Paediatrica Scandinavica, 64, 709-717.

Rolles, C. (1973). Commercial human milk banks in the United Kingdom. Midwives Chronicle, 86, 353-354.

Ryley, H. C. (1972). An immunoelectrophoretic study of the soluble secretory proteins of sputum. Biochimica et Biophysica Acta, 271, 300-309.

Ryley, H. C., and Brogan, T. D. (1973). Quantitative immunoelectrophoretic analysis of the plasma proteins in the sol phase of sputum from patients with chronic bronchitis. Journal of Clinical Pathology, 26, 852-856.

Ryley, H. C., Neale, L. M., Brogan, T. D., and Bray, P. T. (1975). Screening for cystic fibrosis by analysis of meconium for albumin and protease inhibitors. Clinica Chimica Acta, 64, 117-125.

Szöllösy, E., Marjai, E., and Lantos, J. (1974). Bacterial contamination and sparing heat treatment of mother's milk. Acta Microbiologica Academiae Scientiarum Hungaricae, 21, 319-325.

Willis, A. T., Bullen, C. L., Williams, K., Fagg, C. G., Bourne, A., and Vignon, M. (1973). Breast milk substitute: a bacteriological study. British Medical Journal, 4, 67-72.

Correspondence to Dr T. J. Evans, Department of Child Health, University of Wales, Heath Park, Cardiff CF4 4XW. 